\title{
Response of rooted simmondsia chinensis cuttings to foliar fertilizers at different times of year under green-and-shade house conditions
}

\begin{abstract}
The importance of jojoba plants comes due to its multi uses and unique features. It is a desert plant, drought tolerant, salty resistant and adapts well in different types of soil. Jojoba plants produce liquid wax which meets global demand owing to its use in cosmetics and other important aspects of life. Production of high quantities of the jojoba liquid wax needs elite and active plants in the growth. Thus, the objective of these present investigations was to study the effect of fertilizers and time of spray on the vegetative growth of rooted jojoba cuttings. Two experiments were conducted in the greenhouse and shade house using rooted jojoba cuttings and different types of fertilizers such as macronutrients and micronutrients additional to some of sea algae extract either individually or in combinations at four times of year with 30 day intervals under greenhouse and shade house conditions. The results pointed out significant effect by the spray of micronutrient fertilizers compared to other type of fertilizers in both greenhouse and shade house in terms of height of plant and number of shoots and leaves per plant. The fourth spray of fertilizers gave the highest values of the different parameters studied. The interaction between time of spray and type of fertilizers did not differ significantly. Greenhouse condition was more favorable for growth of jojoba rooted cuttings than shade house. This study created an importance of foliar fertilization of jojoba plants by micronutrient fertilizers.
\end{abstract}

Keywords: jojoba, fertilizer, spray, micronutrient, rooted-cuttings
Volume 2 Issue 3 - 2015

\author{
Ahmed M Eed,' Adam H Burgoyne ${ }^{2}$ \\ 'Department of Plant Production, lbb University, Yemen \\ ${ }^{2}$ Jojoba Naturals Corporation, Montevideo, Uruguay \\ Correspondence: Ahmed M Eed, Department of Plant
Production, College of Agriculture and \\ Email ahmede@jojobanaturals.com
}

Received: December 04, 2014 | Published: April 23, 2015
Abbreviations: MA, macronutrients; MI, micronutrients; SAE, sea algae extract; LSD, least significant difference

\section{Introduction}

Jojoba (Simmondsia chinensis (Link) Schneider) is a new industrial crop being grown commercially in hot arid and semiarid regions of the southwestern United States. ${ }^{1}$ The primary product of this evergreen shrub is a unique liquid wax contained in the seed. This wax is used as a natural base for a wide range of cosmetic products, it has heat-resistant lubricating properties, and is potentially useful in the chemical industry. Nutrient requirements are important for good growth of rooted jojoba cuttings particularly when plants rooted under intermittent mist irrigation under greenhouse conditions. These nutritious elements could be secured for jojoba plants easily in the controlled conditions such as green house or shade house using foliar fertilization, especially when plants lose their nutritious contents from leaves due to regulated mist irrigation. Further, treating jojoba plants with different kinds of foliar fertilization in those controlled conditions makes plants grow well and reach a suitable size for planting early. Feldman ${ }^{2}$ reported that leaf contents of N, P and $\mathrm{K}$ were reduced after 12 weeks under intermittent mist and approached deficiency levels for jojoba plants. Therefore early growth following rooting was directly related to leaf concentration of the nutrients either macronutrients or micronutrients. Nursery fertilization with Osmocote (macronutrient fertilizers containing NPK @ 19-6-12 respectively) at either 1.48 or $2.97 \mathrm{~kg} / \mathrm{m}^{3}$ enhanced nursery growth over that of control liners. ${ }^{2}$ Macronutrients are essential for different activities in the plant such as $\mathrm{N}$, which is one of the essential nutrients needed by plants mainly for buildup associated with high photosynthetic activity. ${ }^{3,4}$ Phosphorous
(P) also is an important structural component essential for energy storage and transfer (ADP and ATP) for subsequent use in growth and reproductive processes. ${ }^{5}$ Potassium $(\mathrm{K})$ has important role in increasing water uptake and consequently in cell expansion. ${ }^{3}$ Growth of young olive trees improved with NPK fertilization according to Bouranis et al., ${ }^{4}$ Micronutrient fertilizers such as $\mathrm{Zn}, \mathrm{Mn}$ and B were also related to early growth of rooted cuttings particularly during the spring. Deficiencies can be overcome if proper nutrition is applied to the liners in the nursery stage. However, time required to reach plantable size may then be increased. ${ }^{2}$ Generally, there is lack of information about the potential of rooted jojoba cuttings and its response to different kinds of foliar fertilization. Therefore, the target of these investigations was to study the effect of foliar fertilization of macronutrients (MA), micronutrients (MI) and sea algae extract (SAE) individually or in combinations at different times of year on the growth of rooted Simmondsia chinensis cuttings under green-andshade-house conditions.

\section{Materials and methods}

\section{Plant material}

The investigations were carried out at Jojoba Naturals Company greenhouse and shade house, Sana'a, Yemen during the years 2013 and 2014. The plant material for these two experiments was the rooted cuttings of jojoba plants $(10-12 \mathrm{~cm}$ height), which had been rooted previously by the application of a suitable auxin (IBA) to semi-hardwood cuttings. These rooted cuttings were taken out from rectangular flat trays, which had been kept under intermittent mist propagation conditions for rooting duration, and were transferred to pots 
(polythene bags) filled with potting media (vermiculite+perlite+peat moss; $1: 1: 1)$ and employed in the next two experiments.

\section{Experiment I}

Rooted cuttings of jojoba plants were sprayed with different types of liquid fertilizers i.e., macronutrients (MA) (Bio 20; Omex, Agrifluids, Lmt., England), micronutrients (MI) (Omex; micromax, Agrifluids, Lmt., England), and sea algae extract (SAE) (Gaefol AL-Khair, Chema Industries, Egypt) (use to strengthen root system and increase nutrient uptake) individually and in combinations viz, $\mathrm{MA}+\mathrm{MI}, \mathrm{MA}+\mathrm{SAE}, \mathrm{MI}+\mathrm{SAE}, \mathrm{MA}+\mathrm{MI}+\mathrm{SAE}$ additional to the control (untreated plants), each combination had the same ratio in volume. Plants were kept under greenhouse conditions under temperature range less than $35^{\circ} \mathrm{C}$ by using Pad Cooling System and the humidity range was not more than $60 \%$. Both of them were measured with Hygro-Thermometer device (Jumbo Display Hygro-Thermometer, USA). Treatments were achieved in four periods, starting time was the mid-Dec then mid-Jan, mid-Feb and the mid-March with 30 day intervals during the years 2013 and 2014. Evaluation of obtained data of jojoba plants for different parameters such as height of plant and number of shoots and leaves per plant were calculated for four times, but starting time was from the mid-Jan. to the mid-Apr. Studying only of these three parameters is owing to that these characters give fast reading and perfect view regarding important aspect of plant i.e., growth of plant.

\section{Experiment 2}

Rooted cuttings of jojoba plants were sprayed with the same fertilizers and its combinations in different times of the year as indicated in Experiment 1 but under shad house conditions $(55 \%$ shade). The temperature range in this period was between $11-18^{\circ} \mathrm{C}$ whereas humidity range was between $40-45 \%$. Evaluated parameters were as in Experiment 1.

\section{Experimental design and data analysis}

Experiments were conducted in a factorial completely randomized block design (FCRBD) with three replicates, each with 10 rooted cuttings per replicate. Obtained data of different parameters of rooted jojoba cuttings were subjected to statistical analysis according to Jomez et al. ${ }^{6}$ and Sastry. ${ }^{7}$ ANOVA values were obtained with Opstat1 software (O.P Sheron, Programmer, Computer Section, CCS HAU, Hisar, India) and means were separated with least significant difference (LSD) at $\mathrm{P}=0.05$. Further, comparison of greenhouse and shade house effect on the all parameters studied was done independently according to Systat software, version 10, SPSS, Ine. 2000, by calculating T-test at $\mathrm{P}=0.01 \%$.

\section{Results and discussion}

Growth of rooted jojoba cuttings as affected with different types of fertilizers and spraying times under green house conditions (Table 1). Significantly, the height of plant increased after the first spray by the use of fertilizers in the mid-Dec. to the last spray in the midMarch (13.58 $\mathrm{cm}$ to $19.04 \mathrm{~cm}$ respectively) irrespective of the type of fertilizers. This increase in height of plant is a normal result because of the consumed time between first and last spray which took around 120 days in which the growth of plant was significantly increased. Similarly, the growth of other parameters studied such as number of shoots and leaves per plant took place. This reason is suitable to interpret the result of all parameters studied regarding why the last spray of fertilizers gave the highest value for all characters in both conditions of greenhouse and shade house. Among various types of fertilizers and their combinations, micronutrients yielded significantly the highest height of rooted jojoba cuttings $(18.58 \mathrm{~cm})$ compared to other type of fertilizers except with macronutrient fertilizers, there was no significant difference $(18.50 \mathrm{~cm})$. The least height of rooted jojoba cuttings $(13.29 \mathrm{~cm})$ was recorded with the spray comprising $\mathrm{MA}+\mathrm{MI}+\mathrm{SAE}$.

Number of shoots per rooted jojoba cutting did not differ significantly at all time of sprays regardless of the type of fertilizers used. The greatest number of shoots per plant (4.66) was observed with the spray of micronutrient fertilizers in comparison with other type of fertilizers whereas the least number of this character $(2.50)$ was recorded with spray containing MA+MI+SAE.

Regarding number of leaves per plant, it was similar to those mentioned in the first and second parameters in which the highest number of leaves per plant was seen after spray of fertilizers in the mid-March whereas the lowest number of leaves per plant was noticed after the first spray of fertilizers in the mid-Dec. irrespective of the time of spray of fertilizers. Significantly, the greatest number of leaves (27.75) was recorded by the spray with micronutrient fertilizers but the least number of leaves (11.25) was gained by the spray with treatment containing MA+MI+SAE. The ideal type of foliar spray fertilizer was the micronutrient fertilizer in majority of parameters studied, this might be due to bleaching of some nutritional elements from plant leaves either macro or micro elements. Therefore, the plant element's requirement was higher from the micronutrient fertilizers over other type of fertilizers and this result appeared clearly almost in all parameters investigated. Regarding why the spray containing $\mathrm{MA}+\mathrm{MI}+\mathrm{SAE}$ yielded the lowest value almost in all parameters studied, this could be due to weakness uptake of elements by plant foliage when added at one time, perhaps some clashing was created among cations and anions of different elements either macro or micro elements.

The data of interaction between time of sprays and type of fertilizers regarding height of plant and number of shoots and leaves per plant was illustrated (Figure 1-3). The results indicated differences among different values of the various parameters but with no significant difference.

Table 2 shows the effect of time of spray and type of fertilizers in terms of height of plant, number of shoots and leaves per plant on the growth of rooted jojoba cuttings under shade house conditions. The greatest height of plant $(22.91 \mathrm{~cm})$ was obtained markedly after the fourth spray of fertilizers in the mid-March irrespective of the type of spray of fertilizers, this was followed by the third spray of fertilizers $(21.50 \mathrm{~cm})$ which was in the mid-Feb. and then the second spray of fertilizers $(18.29 \mathrm{~cm})$ which was in the mid-Jan. whereas the lowest value of this character was recorded after the first spray of fertilizers $(13.91 \mathrm{~cm})$ which was in the mid-Dec. The fertilizer factor affected significantly the height of jojoba rooted cuttings. The spray of rooted jojoba cuttings by the use of micronutrient fertilizers yielded higher height of plant than the plant sprayed with SAE and MA+MI+SAE but lower than the plant sprayed with MA, MA+MI, MA+SAE, and MI+SAE. The lowest height of plant $(11.25 \mathrm{~cm})$ was performed with the spray consisting of MA+MI+SAE.

The values of number of shoots per rooted jojoba cuttings diversified significantly. The most number of shoots per plant (2.45) 
was noticed after the fourth spray of fertilizers whereas the lowest number of this character (1.41) was observed after the first spray of fertilizers. No significant difference was observed among different types of fertilizers in terms of the number of shoots per plant. Pertaining to the number of leaves per plant, the values had significant difference. Similarly, as in the first two characters (height of plant and number of shoots per plant), the fourth time of spray in the midMarch gave the highest number of leaves per plant (15.94) whereas the lowest number of leaves per plant (13.37) was recorded after the first time of spray of fertilizers. The control plants markedly gave the highest number of leaves per plant (16.67) compared to all types of sprayed plants by different type of fertilizers. The least number of this character (12.58) was performed with the spray of MI fertilizers.

The data of interaction between time of sprays and type of fertilizers regarding height of plant and number of shoots and leaves per plant was illustrated (Figure 4-6). The results pointed out differences among different values of the various parameters but with no significant effect.
A comparison was made between greenhouse and shade house conditions independently on the all parameters studied after treated jojoba rooted cuttings with different fertilizers used (Table 3). It is clearly seen that green house condition was more favorable for the growth of plant particularly for the height of plant and no. of shoots and leaves per plant of jojoba rooted cuttings than shade house condition. On the other hand, the difference in means between greenhouse and shade house conditions for all parameters investigated pointed out that the green house condition was better with significant effect for height of plant or high significant effect for number of shoots and leaves per plant at $\mathrm{P}=0.01 \%$ in comparison with shade house conditions. This superiority of greenhouse condition versus shade house condition might be attributed to the nature of conditions inside greenhouse; where optimal temperature and relative humidity are supplied to plants and there was no loss in the fertilizers' quantities when plants sprayed due to controlled condition.

In general, foliar fertilization using micronutrients fertilization was the best compared to other types of fertilizations with its combinations in the greenhouse over shade house conditions.

Table I Effect of time of spry and fertilizers on the growth of jojoba plants under greenhouse conditions

\begin{tabular}{|c|c|c|c|}
\hline Treatment & Height of plant (Mean)* & No. of branches/Plant (Mean)* & No. of leaves/Plant (Mean)* \\
\hline \multicolumn{4}{|l|}{ Time of Sprayz (TZ) } \\
\hline Mid-Dec. 2013 & $13.58 \mathrm{c}$ & $3.00 \mathrm{a}$ & $13.91 \mathrm{c}$ \\
\hline Mid-Jan. 2014 & $14.70 \mathrm{bc}$ & $3.62 \mathrm{a}$ & $18.29 b$ \\
\hline Mid-Feb. 2014 & $16.52 b$ & $3.45 \mathrm{a}$ & $21.50 \mathrm{ab}$ \\
\hline Mid March 2014 & $19.04 \mathrm{a}$ & $3.75 \mathrm{a}$ & $22.91 \mathrm{a}$ \\
\hline \multicolumn{4}{|l|}{ Fertilizer Type (FT) } \\
\hline Macronutrients (MA) & $18.50 \mathrm{a}$ & $3.08 \mathrm{bc}$ & $21.33 \mathrm{bc}$ \\
\hline Micronutrients (MI) & $18.58 \mathrm{a}$ & $4.66 \mathrm{a}$ & $27.75 \mathrm{a}$ \\
\hline Sea Algae Extract (SAE) & $15.00 \mathrm{bc}$ & $3.00 \mathrm{c}$ & $14.33 \mathrm{~d}$ \\
\hline MA+MI & $14.04 \mathrm{bc}$ & $3.41 \mathrm{abc}$ & $18.08 \mathrm{bcd}$ \\
\hline $\mathrm{MA}+\mathrm{SAE}$ & $15.45 \mathrm{bc}$ & $3.33 b c$ & $22.75 b$ \\
\hline MI+SAE & $16.95 \mathrm{ab}$ & $4.50 \mathrm{ab}$ & $20.50 \mathrm{bc}$ \\
\hline $\mathrm{MA}+\mathrm{MI}+\mathrm{SAE}$ & $13.29 \mathrm{c}$ & $2.50 \mathrm{c}$ & $11.25 \mathrm{e}$ \\
\hline Control & $15.87 \mathrm{abc}$ & $3.16 \mathrm{c}$ & $17.25 \mathrm{~cd}$ \\
\hline
\end{tabular}

*Similar letters indicate means which are not significantly different ( $L S D, P=0.05)$, comparisons are made in each column within TS and FT, values represent as means. zSpray was on the plant foliage. 
Table 2 Effect of time of spry and fertilizers on the growth of jojoba plants under shade house conditions

\begin{tabular}{|c|c|c|c|}
\hline Treatment & Height of plant (Mean)* & No. of branches/Plant (Mean)* & No. of leaves/Plant (Mean)* \\
\hline \multicolumn{4}{|l|}{ Time of Sprayz (TZ) } \\
\hline Mid-Dec. 2013 & $13.91 \mathrm{c}$ & $1.41 \mathrm{~b}$ & $13.37 \mathrm{~b}$ \\
\hline Mid-Jan. 2014 & $18.29 \mathrm{~b}$ & $1.79 \mathrm{ab}$ & $14.00 \mathrm{~b}$ \\
\hline Mid-Feb. 2014 & $21.50 \mathrm{ab}$ & $2.00 \mathrm{ab}$ & $14.91 \mathrm{ab}$ \\
\hline Mid March 2014 & $22.91 \mathrm{a}$ & $2.45 \mathrm{a}$ & $15.94 \mathrm{a}$ \\
\hline \multicolumn{4}{|l|}{ Fertilizer Type (FT) } \\
\hline Macronutrients (MA) & $21.33 \mathrm{bc}$ & $1.50 \mathrm{a}$ & $12.79 \mathrm{~cd}$ \\
\hline Micronutrients (MI) & $27.75 \mathrm{a}$ & $2.58 \mathrm{a}$ & $12.58 \mathrm{~d}$ \\
\hline Sea Algae Extract (SAE) & $14.33 \mathrm{de}$ & $2.16 \mathrm{a}$ & $14.12 \mathrm{bcd}$ \\
\hline $\mathrm{MA}+\mathrm{MI}$ & $18.08 \mathrm{bcd}$ & $1.33 \mathrm{a}$ & $15.25 \mathrm{ab}$ \\
\hline $\mathrm{MA}+\mathrm{SAE}$ & $22.75 b$ & $1.33 \mathrm{a}$ & 14.70abcd \\
\hline $\mathrm{MI}+\mathrm{SAE}$ & $20.50 \mathrm{bc}$ & $2.08 \mathrm{a}$ & $14.83 \mathrm{abc}$ \\
\hline $\mathrm{MA}+\mathrm{MI}+\mathrm{SAE}$ & $11.25 \mathrm{e}$ & $2.16 \mathrm{a}$ & $15.50 \mathrm{ab}$ \\
\hline Control & $17.25 \mathrm{~cd}$ & $2.16 \mathrm{a}$ & $16.67 \mathrm{a}$ \\
\hline
\end{tabular}

*Similar letters indicate means which are not significantly different (LSD,P=0.05), comparisons are made in each column within TS and FT, values represent as means. zSpray was on the plant foliage.

Table 3 Comparison between effect of greenhouse and shade conditions on growth parameters of jojoba rooted cuttings when sprayed with different fertilizers

\begin{tabular}{|c|c|c|c|}
\hline & $\begin{array}{l}\text { Height of plant } \\
(\mathrm{cm})\end{array}$ & No. of branches/Plant & No. of leaves/Plant \\
\hline & Mean \pm SD & $\operatorname{Mean} \pm$ SD & $\operatorname{Mean} \pm$ SD \\
\hline Green House (G) & $15.96 \pm 3.16$ & $3.35 \pm 0.82$ & $19.15 \pm 6.51$ \\
\hline Difference in Means between G \& S & $1.40 *$ & $1.54 * *$ & $9.58 * *$ \\
\hline
\end{tabular}

Comparisons were made between $\mathrm{G} \& \mathrm{~S}$ in each column, *means presence of significance between difference in means, and $*^{*}$ means presence of high significance between difference in means according to T-test at $\mathrm{P}=0.01 \%$, SD: Standard Deviation.

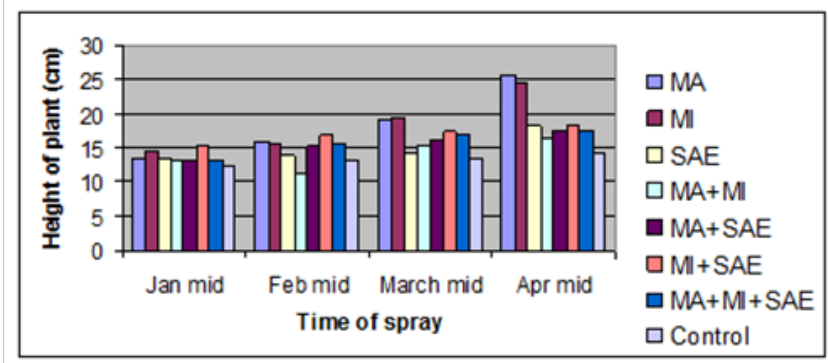

Figure I Effect of time of foliar spray and type of fertilizations on height of plant $(\mathrm{cm})$ under greenhouse conditions.

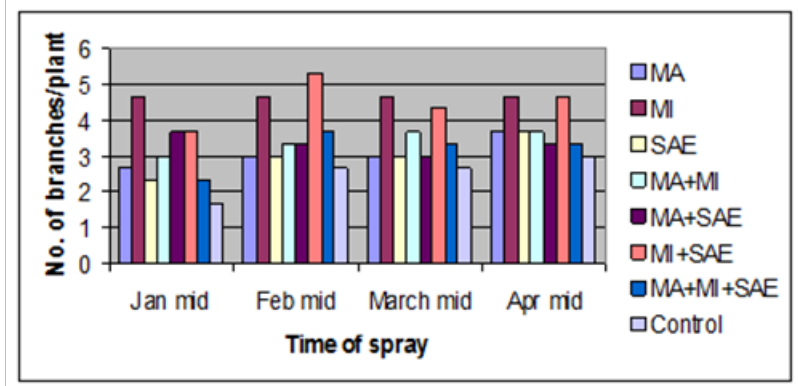

Figure 2 Effect of time of foliar spray and type of fertilizations on no. of branches per plant under greenhouse conditions. 


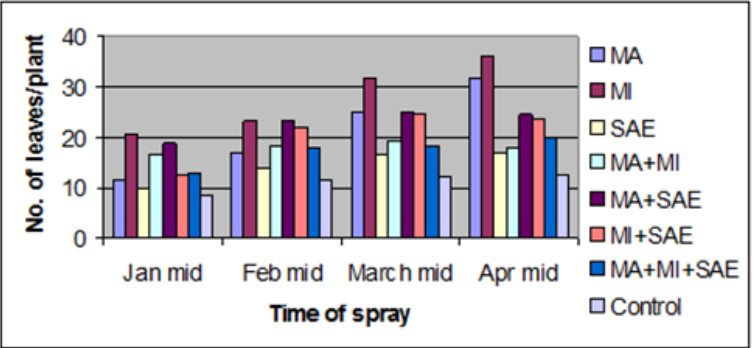

Figure 3 Effect of time of foliar spray and type of fertilizations on no. of leaves per plant under greenhouse conditions.

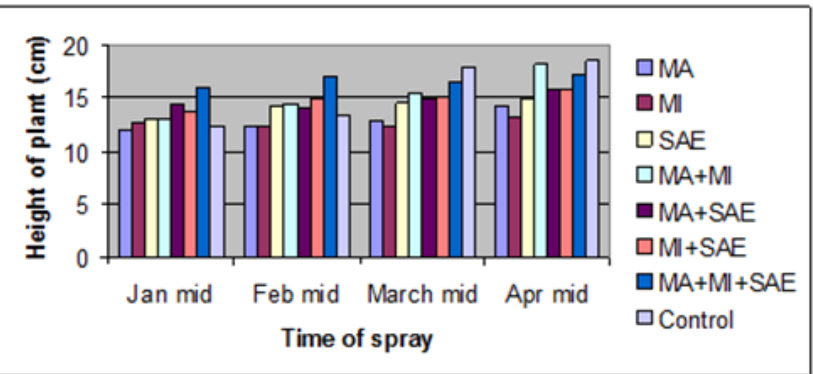

Figure 4 Effect of time of foliar spray and type of fertilizations on height of plant $(\mathrm{cm})$ under shade house conditions.

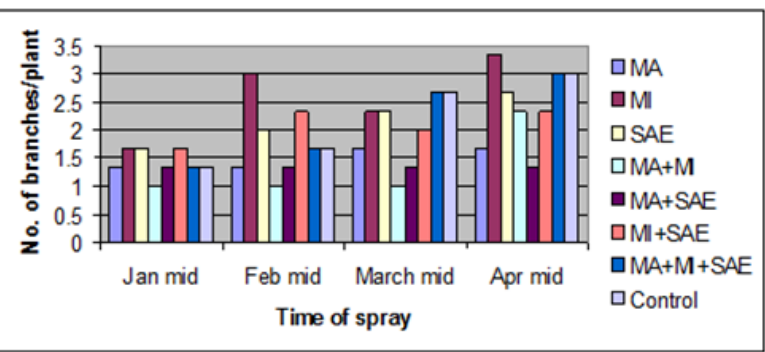

Figure 5 Effect of time of foliar spray and type of fertilizations on no. of branches per plant under shade house conditions.

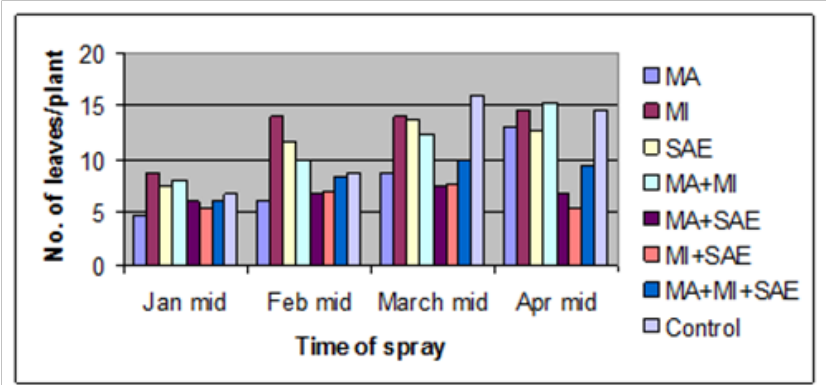

Figure 6 Effect of time of foliar spray and type of fertilizations on no. of leaves per plant under shade house conditions.

\section{Conclusion}

Jojoba plants seem to have better growth after the forth spray in the mid-March by the use of micronutrient fertilizers in both green-andshade house conditions in comparisons with other time of sprays and type of foliar fertilizations. Fertilization of plants in the greenhouse was better than in the shade house. The findings could be of great value to the nursery men to spray their rooted jojoba cuttings by foliar application of micronutrient fertilizers especially when plants rooted under mist irrigation system.

\section{Acknowledgements}

None.

\section{Conflict of interest}

The author declares no conflict of interest.

\section{References}

1. National Research Council. Jojoba: New Crop for Arid Lands, New Raw Material for Industry. Washington, DC, USA: National Academy Press; 1985.

2. Feldman, Raoul W. Nutrition and growth of jojoba, (ink) Schneider, during vegetative propagation. $\mathrm{PhD}$ dissertation, USA: The University of Arizona; 1982.

3. Jasrotia A, Singh RP, Singh JM, et al. Response of olive trees to varying levels of $\mathrm{N}$ and $\mathrm{K}$ fertilizers. Third international symposium on olive growing, Chania, Greece, Acta-Horticulturae. 1999;474:337-340.

4. Bouranis D, Zakinathinos G, Kapetanos Ch, et al. Dynamics of nitrogen and phosphorus partition in four olive tree cultivars during bud differentiation. J Plant Nutr. 2001;24(10):1535-1550.

5. Mengel K, Kirkby E. Principles of plant nutrition. 3rd ed. Eugene, USA: International Potash Institute; 1982.

6. Gomez KA, Gomez AA. Statistical procedures for agricultural research. New York, USA: John Wiley \& Sons; 1983. p. 298-308.

7. Sastry EVD. Essentials of Agricultural Statistics. Jaipur, Rajasthan, India: Pointer Publishers; 2007. p. 260-266. 